Markku Lehtimäki

Kirjallisuus, Itä-Suomen yliopisto

\title{
Kirjallinen kulttuuri muuttuvassa maailmassa
}

Itä-Suomen yliopiston kirjallisuusoppiaine on jo pitkään pyrkinyt sijoittamaan itsensä muuttuvaan yhteiskunnalliseen todellisuuteen, reagoimaan uusien teknologioiden ja mediamuotojen esittämiin haasteisiin sekä ylipäänsä reflektoimaan "kirjallisuuden" määrittelyä historiallisesta ja institutionaalisesta näkökulmasta. Vaikka huomioimme kirjallisuushistorian ja kaunokirjallisuuden klassikoiden merkityksen opetuksessa, tiedostamme samalla, että kirjallisuus on merkityksellinen tapa puhua aikamme globaalista maailmasta ja sen teknologisista, ekologisista, nationalistisista ja uusliberalistisista ongelmista.

Oppialana kirjallisuus on jatkuvassa muutoksessa. Itä-Suomen yliopiston kirjallisuus on jo vuosien ajan toiminut perustalla, jossa on luovuttu puhtaan autonomisesta oppiaineajattelusta ja jossa on rakennettu valmiuksia laaja-alaisiin kandidaatinohjelmiin ja monitieteisiin maisteriohjelmiin. Onkin selvää, että nykyiset ja erityisesti tulevat opetussuunnitelmat vaativat kirjallisuustiedettä määrittelemään uudelleen identiteettiään ja profiiliaan laajemmalla humanistisella kielen- ja kulttuurintutkimuksen kentällä ja huomioimaan myös koulumaailman - erityisesti lukion äidinkielen ja kirjallisuuden opetuksen - muuttuvat opetussuunnitelmat, joissa yhä enemmän korostuu medialukutaito ja monikulttuurisuuden ymmärtäminen.

Joensuussa kirjallisuus ei ole erillinen hakukohde, vaan hakijat tulevat kirjallisuuden pääaineopiskelijoiksi kahta erillistä reittiä. Suomen kielen ja kirjallisuuden hakukohteen kautta hakija saa pääaineoikeuden suomen kieleen ja kirjallisuuteen, joista toinen valitaan pääaineeksi, ja kulttuurintutkimuksen koulutusohjelman kautta hakija saa pääaineoikeuden kirjallisuuteen, kulttuuriantropologiaan, mediakulttuuriin ja viestintään, musiikkitieteeseen, perinteentutkimukseen, sukupuolentutkimukseen ja taiteensosiologiaan. Pääaine valikoituu tältä monitieteiseltä pohjalta opintojen aikana, ja kirjallisuuden vetovoimaisuudesta kertoo se, että meille valikoituu vuosittain hyvä määrä pääaineopiskelijoita näiden kahden hakukohteen - suomen kielen ja kulttuurintutkimuksen - kautta. Päätavoitteenamme on kouluttaa kulttuurin ja kirjallisuuden ammattilaisia äidinkielen ja kirjallisuuden opettajiksi sekä muihin vaativiin asiantuntijatehtäviin, niin tutkijoiksi kuin taide- ja kulttuurialan töihin.

Hakukuulutuksessamme kerrotaan kirjallisuuskäsityksemme ydin, jonka mukaan kirjallisuus on ajatuksen ja kielen taidetta, joka reagoi ympäristöönsä ja joka esiintyy niin romaaneissa, matkakertomuksissa, rock-lyriikassa, peleissä kuin blogeissa. Tätä kaikkea Itä-Suomen kirjallisuus opettaa ja tutkii: erityisesti suomalaista kaunokirjalli- 
suutta ja tiettyjä kirjailijoita (Veijo Meri, Timo K. Mukka, Sofi Oksanen, Juha Seppälä), ei-fiktiivistä kirjallisuutta (kuten valokuvadokumentarismia), tietokonepelejä, digitaalista kulttuuria ja sosiaalista mediaa, sarjakuvaa, elokuvaa ja muita visuaalisia muotoja sekä rock-lyriikkaa kirjallisuutena - mistä syystä Bob Dylanille myönnetty Nobelin kirjallisuuspalkinto sopii aukottomasti laaja-alaiseen kirjallisuuskäsitykseemme.

Näin ollen kirjallisuus tarkastelee ja osaltaan säilyttää tärkeää kulttuuriperintöä samalla kun se murtaa rakenteita ja käsityksiä, joita on saatettu pitkään pitää itsestäänselvyyksinä. Joensuulaisessa kirjallisuuskäsityksessä on vahva kirjallisuussosiologinen lähtökohta, jonka pohjalta kirjallisia teoksia ja kirjallista elämää tarkastellaan kulttuurisyhteiskunnallisena ilmiönä ja sosiaalisena järjestelmänä. Toinen vallitseva linja, kulttuurintutkimuksellinen näkökulma, tutkii puolestaan kirjallisuutta suhteessa kulttuurisiin konteksteihin, joita ovat esimerkiksi sukupuoli, etnisyys, kansallisuus sekä kulttuuri- ja kirjallisuushistoria. Kolmantena painopistealueena on ollut kirjallisuusteoreettinen ja filosofinen kirjallisuudentutkimus, joka kohdistuu teoreettisten ja metodisten hahmotusten soveltamiseen ja kehittämiseen. Näissä puitteissa oppiaineen sisällä tehdyssä tutkimuksessa ovat olleet edustettuina muun muassa taidemaailman instituutioiden tutkimus, suomalaisten kirjallisuuskäsitysten kehittyminen, kertomuksen teoria (niin strukturalistinen, retorinen kuin hermeneuttinen), postmodernin ja metafiktion tutkimus, feministinen kirjallisuusteoria sekä kirjallisuuden ja muun median välisten suhteiden analyysi.

Viimeaikaisessa oppiaineen sisällä tehdyssä tutkimuksessa on tarkasteltu muun muassa taidemaailmojen ja taideinstituutioiden markkinallistumista (professori Erkki Seväsen johtama Suomen Akatemian tutkimushanke 2011-2014), kirjallisia rajaseutuja ja muuttuvia tekstuaalisia ympäristöjä (professori Risto Turunen), sota- ja jälleenrakennusajan uudelleentulkintoja erityisesti naisten kirjoittamissa nykyromaaneissa (yliopistonlehtori Elina Arminen) sekä kertomusmuodon ja luonnollisen ympäristön suhteita kaunokirjallisissa ja visuaalisissa esityksissä (yliopistonlehtori Markku Lehtimäki). Kirjan muodossa on viime vuosina ilmestynyt niin kirjallisuussosiologinen antologia Paluu maailmaan (2011) kuin taiteen institutionaalista tutkimusta käsittelevä Taide ja maailma (2015), jotka molemmat toimivat johdatuksina joensuulaiseen kirjallisuuskäsitykseen. Kirjallisuus on viime vuosina järjestänyt myös kansainvälisiä konferensseja ja symposiumeja kuten Literary Culture in Contemporary Market Capitalism (2012) ja Worlds, Meanings and Markets of Fiction (2014). Lisäksi viimeisen vuoden aikana oppiaineessa on väitelty yhtäältä jäljen ja korvattavuuden derridalaisista käsitteistä ja toisaalta suomalaisen taidemaailman provokatiivisista tapauksista. Uutta tutkimusta kirjallisuusoppiaineen piirissä on tulossa liittyen muun muassa veden kaunokirjallisiin kuvauksiin ja vettä koskeviin kulttuurisiin käsityksiin, 2000-luvun suomalaisen romaanin muotoihin ja merkityksiin sekä kirjallisuuden ja kirjallisuusjärjestelmän muutoksiin globaalin kapitalismin aikakaudella. 